\title{
Synthesis of dehydrobenzoannulenes with pyrene core
}

\author{
ANTONY JOSEPH, GANDIKOTA VENKATARAMANA \\ and SETHURAMAN SANKARARAMAN* \\ Department of Chemistry, Indian Institute of Technology Madras, Chennai 600 036, India \\ e-mail: sanka@iitm.ac.in
}

MS received 9 January 2012; revised 11 February 2012; accepted 8 March 2012

\begin{abstract}
Synthesis of dehydrobenzoannulenes (DBAs) with pyrene core from 1,8-diethynylpyrene and 1,3,6,8-tetraethynylpyrene as building blocks is reported. A sequence involving Sonogashira coupling, CoreyFuchs reaction and oxidative coupling (Eglinton coupling) is used for the synthesis of pyrene-based dehydrobenzoannulenes. Due to the presence of pyrenechromophore these DBAs and their precursors are highly fluorescent and emit in the visible region, due to extended conjugation of the acetylenic units with the pyrene core.
\end{abstract}

Keywords. Pyrene; dehydrobenzoannulene; acetylene; fluorescence.

\section{Introduction}

Dehydrobenzoannulenes (DBAs), also known as benzocyclynes have been known for a long time. ${ }^{1}$ They are benzoannulenes in which the olefinic bonds are replaced by acetylenic bonds and hence the name dehydrobenzoannulenes. Initial interest in this class of compounds emerged from the stabilization of dehydroannulenes by fusing an aromatic ring and the study of tropicity (diamagnetic and paramagnetic) of the annulenes. Recently DBAs have attracted great deal of interest as a result of their applications as precursors for new forms of carbon allotropes, ${ }^{2}$ as building blocks and model systems for $2 \mathrm{D}$ carbon networks ${ }^{3}$ and their potential application as optoelectronic materials. ${ }^{4}$ Interest in their aromatic/antiaromatic properties also continues as some of the DBAs serve as sensitive probes for the study of tropicity of the annulene ring. ${ }^{5}$ The synthesis of DBAs has been made facile with the development of $\mathrm{Pd}(0)$ catalysed $\mathrm{C}-\mathrm{C}$ bond forming reactions, especially those involving connection of $\mathrm{sp}^{2}$-sp and sp-sp carbons. ${ }^{6}$ DBAs of different $\pi$-topologies have been synthesized in an effort to understand the structure property relationships. ${ }^{7}$ We have reported the syntheses and structures of cross-conjugated DBAs bearing Y-enediyne motifs. ${ }^{8}$ Most of the DBAs known till date have a benzene or thiophene ring fused to the dehydroannulene ring. Reports of DBAs with fusion of higher polycyclic aromatic hydrocarbons are scarce. Synthesis and tropicity of dimethyldihydropyrene-DBA

*For correspondence hybrids ${ }^{9}$ and [2.2]paracyclophane-DBA hybrids have been reported. ${ }^{10}$ Recently DBAs with triphenylene core have been reported. ${ }^{11}$

We report here the synthesis and spectroscopic properties of DBAs with a pyrene ring. Pyrene is a prototypical fluorescent polycyclic aromatic hydrocarbon. ${ }^{12}$ We have studied the effect of acetylenic conjugation on the fluorescence emission of ethynylpyrenes. ${ }^{13}$ For example 1,3,6,8-tetraethynylpyrene has been reported for the first time from our laboratory, ${ }^{13}$ which can be used as a building block in acetylenic scaffolds of larger molecular systems.

\section{Experimental}

1,8-Diethynylpyrene (2) ${ }^{14}$ and iodides $\mathbf{3 a - c} \mathbf{c}^{15}$ were synthesized by reported procedures and were characterized by spectroscopic techniques. Reactions were carried out under nitrogen atmosphere unless stated otherwise.

\subsection{General procedure for the preparation of $\mathbf{4 a - c}$}

3a-c $\left.(2.4 \mathrm{mmol}),\left[\mathrm{PdCl}_{2}\left(\mathrm{PPh}_{3}\right)_{2}\right](0.06 \mathrm{eq}, 0.14 \mathrm{mmol})\right)$, $\mathrm{CuI}$ (0.03 eq, $0.07 \mathrm{mmol}), \mathrm{PPh}_{3}(0.06 \mathrm{eq}, 0.14 \mathrm{mmol})$ were added to a degassed solution of diisopropylamine $(25 \mathrm{~mL})$ and THF $(20 \mathrm{~mL})$. The reaction mixture was heated at $50^{\circ} \mathrm{C}$ for $30 \mathrm{~min}$. The reaction mixture was cooled to room temperature and then a solution of 1,8ethynylpyrene (2) $(1.0 \mathrm{mmol})$ dissolved in degassed 
THF was added drop-wise using a syringe. After complete addition, the mixture was heated at $50^{\circ} \mathrm{C}$. Reaction was monitored by TLC. After completion of the reaction, the mixture was cooled to room temperature and poured into ice cold $2 \mathrm{~N} \mathrm{HCl}(25 \mathrm{~mL})$. The reaction mixture was extracted with $\mathrm{CH}_{2} \mathrm{Cl}_{2}(2 \times 20 \mathrm{~mL})$. The organic layer was further washed with brine solution and dried over anhydrous $\mathrm{Na}_{2} \mathrm{SO}_{4}$ and evaporated the solvent under reduced pressure. Column chromatographic purification of the crude product on silica gel with hexane/dichloromethane as eluent furnished pure 4a-c.

2.1a 1,8-Bis-((4,5-bis(decyloxy)-2-((trimethylsilyl)ethynyl)phenyl)ethynyl)pyrene (4a): Yield $22 \%$ (0.27g, $0.20 \mathrm{mmol}$ from $1.46 \mathrm{~g}, 2.40 \mathrm{mmol}$ of 3a), Waxy solid, IR (neat): 2961, 2922, 2853, 2372, 2339, 2147, 1507, $1465,1260 \mathrm{~cm}^{-1}$; UV-Vis $\left(\mathrm{CH}_{2} \mathrm{Cl}_{2}\right) \lambda_{\max }(\log \varepsilon) 440$ (4.60), 420 (4.63), 365 (4.27), 341 (4.46), 327 (4.45), 275 (4.67), 251 (4.92) nm; ${ }^{1} \mathrm{H}$ NMR (400 MHz, $\mathrm{CDCl}_{3}$ ) $\delta=8.89(\mathrm{~s}, 2 \mathrm{H}), 8.23(\mathrm{~d}, J=8.0 \mathrm{~Hz}, 2 \mathrm{H}), 8.08(\mathrm{~d}, J=$ $8.0 \mathrm{~Hz}, 2 \mathrm{H}), 7.99$ (s, 2H), $7.14(\mathrm{~s}, 2 \mathrm{H}), 4.01(\mathrm{~m}, 8 \mathrm{H}), 1.8$ $(\mathrm{m}, 8 \mathrm{H}), 1.27(\mathrm{~m}, 56 \mathrm{H}), 0.85(\mathrm{~m}, 12 \mathrm{H}), 0.31(\mathrm{~s}, 18 \mathrm{H})$; ${ }^{13} \mathrm{C}$ NMR $\left(100 \mathrm{MHz}, \mathrm{CDCl}_{3}\right): 149.2,149.1,131.1$, $130.9,129.7,127.5,126.5,124.6,123.9,118.8,118.5$, 118.3, 116.3, 115.7, 103.9, 96.6, 94.4, 90.7, 68.9, 31.6, 29.3, 29.3, 29.2, 29.1, 29.0, 28.9, 28.8, 25.7, 25.6, $22.4,13.8,0.7$; MALDI-TOF MS $\left(\mathrm{C}_{82} \mathrm{H}_{114} \mathrm{O}_{4} \mathrm{Si}_{2}\right)$ : $1218\left[\mathrm{M}^{+}\right]$.

$2.1 \mathrm{~b}$ 1,8-Bis-((4,5-bis(dodecyloxy)-2-((trimethylsilyl)ethynyl)phenyl)ethynyl)pyrene (4b): Yield 19\% (0.25 g, $0.19 \mathrm{mmol}$ from $1.60 \mathrm{~g}, 2.40 \mathrm{mmol}$ of $3 \mathbf{b}$ ), waxy solid, IR (neat): 2960, 2922, 2853, 2372, 2340, 2147, 1594, $1507,1465,1260,1021 \mathrm{~cm}^{-1}$; UV-Vis $\left(\mathrm{CH}_{2} \mathrm{Cl}_{2}\right) \lambda_{\max }$ $(\log \varepsilon) 440$ (4.66), 420 (4.71), 366 (4.42), 342 (4.57), 327 (4.57), 275 (4.75), 242 (5.01) nm; ${ }^{1} \mathrm{H}$ NMR $\left(400 \mathrm{MHz}, \mathrm{CDCl}_{3}\right) \delta=8.88(\mathrm{~s}, 2 \mathrm{H}), 8.13(\mathrm{q}, J=$ $8.0 \mathrm{~Hz}, 4 \mathrm{H}), 8.06(\mathrm{~s}, 2 \mathrm{H}), 7.13(\mathrm{~s}, 2 \mathrm{H}), 7.04(\mathrm{~s}, 2 \mathrm{H})$, $4.03(\mathrm{~m}, 8 \mathrm{H}), 1.80(\mathrm{~m}, 8 \mathrm{H}), 1.27(\mathrm{~m}, 72 \mathrm{H}), 0.85(\mathrm{~m}$, $12 \mathrm{H}), 0.28(\mathrm{~s}, 18 \mathrm{H}) ;{ }^{13} \mathrm{C}$ NMR $\left(100 \mathrm{MHz}, \mathrm{CDCl}_{3}\right)$ : 149.0, 148.9, 131.4, 130.9, 129.8, 127.6, 126.5, 124.7, $124.0,118.7,118.5,118.2,116.2,115.5,103.8,96.6$, $94.3,90.7,68.8,68.9,316,29.5,29.4,29.3,29.1$, 28.9, 28.8, 25.7, 22.4, 13.8, 0.7; MALDI-TOF MS $\left(\mathrm{C}_{90} \mathrm{H}_{130} \mathrm{O}_{4} \mathrm{Si}_{2}\right): 1330\left[\mathrm{M}^{+}\right]$.

2.1c 1,8-Bis-((4,5-bis(hexadecyloxy)-2-((trimethylsilyl)ethynyl)phenyl)ethynyl)pyrene (4c): Yield $18 \%$ (0.25 g, $0.16 \mathrm{mmol}$ from $1.87 \mathrm{~g}, 2.40 \mathrm{mmol}$ of $\mathbf{3 c}$ ) waxy solid, IR (neat): 2959, 2922, 2853, 2373, 2340, 2275, 2147 ,
$1595,1507,1465,1260 \mathrm{~cm}^{-1}$; UV-Vis $\left(\mathrm{CH}_{2} \mathrm{Cl}_{2}\right) \lambda_{\max }$ $(\log \varepsilon) 440$ (4.48), 422 (4.54), 365 (4.31), 341 (4.42), 328 (4.45), 295 (4.56), 275 (5.86) nm; ${ }^{1} \mathrm{H}$ NMR $\left(400 \mathrm{MHz}, \mathrm{CDCl}_{3}\right) \delta=8.87(\mathrm{~s}, 2 \mathrm{H}), 8.12(\mathrm{q}, J=$ $8.0 \mathrm{~Hz}, 4 \mathrm{H}), 8.05(\mathrm{~s}, 2 \mathrm{H}), 7.13(\mathrm{~s}, 2 \mathrm{H}), 7.04(\mathrm{~s}, 2 \mathrm{H})$, $4.02(\mathrm{~m}, 8 \mathrm{H}), 1.83(\mathrm{~m}, 8 \mathrm{H}), 1.24(\mathrm{~m}, 104 \mathrm{H}), 0.85(\mathrm{~m}$, $12 \mathrm{H}), 0.28(\mathrm{~s}, 18 \mathrm{H}) ;{ }^{13} \mathrm{C} \mathrm{NMR}\left(100 \mathrm{MHz}, \mathrm{CDCl}_{3}\right)$ : 149.1, 148.9, 131.4, 131.0, 127.6, 126.5, 124.7, 124.0, $118.8,118.6,118.2,116.3,115.6,103.9,69.6,94.4$, $90.7,69.0,68.9,31.6,29.6,29.5,29.4,29.4,29.3$, $29.2,29.1,28.9,28.8,25.7,25.6,22.4,13.8,0.1$; MALDI-TOF MS $\left(\mathrm{C}_{106} \mathrm{H}_{162} \mathrm{O}_{4} \mathrm{Si}_{2}\right): 1578\left[\mathrm{M}^{+}+\mathrm{Na}\right]$.

\subsection{General procedure for the preparation of dehydrobenzoannulenes $\mathbf{1 a}-\boldsymbol{c}$}

A solution of $\mathbf{4 a}-\mathbf{c}(0.13 \mathrm{mmol})$ dissolved in degassed THF $(15 \mathrm{~mL})$ was treated with $n$ - $\mathrm{Bu}_{4} \mathrm{NF}$ (0.1 eq.) and the resulting mixture was stirred at room temperature for $30 \mathrm{~min}$. Progress of the reaction was monitored by TLC. After the reaction was complete the reaction mixture was transferred to another round bottom flask that contained $\mathrm{Cu}(\mathrm{OAc})_{2} \cdot \mathrm{H}_{2} \mathrm{O}$ (3 eq.) dissolved in $10 \mathrm{~mL}$ acetonitrile/pyridine (4:1) mixture. The reaction mixture was stirred at room temperature for $6-8 \mathrm{~h}$. During this period a yellow precipitate appeared. The reaction mixture was neutralized with $5 \%$ aqueous $\mathrm{HCl}$ and extracted with dichloromethane $(20 \mathrm{~mL} \times 2)$. The organic layer was washed with water $(15 \mathrm{~mL} \times 2)$, dried over $\mathrm{Na}_{2} \mathrm{SO}_{4}$ and solvent was evaporated to dryness. Crude product was purified by column chromatography on silica gel using hexane and dichloromethane as eluent to yield 1a-c.

2.2a Dehydrobenzoannulene 1a: Yield 20\% (0.03 g, $0.03 \mathrm{mmol}$ from $0.15 \mathrm{~g}, 0.13 \mathrm{mmol}$ of $4 \mathbf{a})$, yellow colour solid, mp $67^{\circ} \mathrm{C}$, IR (neat): 2923, 2852, 2373, 2339, 1591, 1506, 1466, 1249, $1206 \mathrm{~cm}^{-1}$; UV-Vis $\left(\mathrm{CH}_{2} \mathrm{Cl}_{2}\right) \lambda_{\max }(\log \varepsilon) 450$ (4.47), 425 (4.35), 410 (4.45), 370 (5.25), 307 (4.80), 295 (4.70) nm; ${ }^{1} \mathrm{H}$ NMR $\left(400 \mathrm{MHz}, \mathrm{CDCl}_{3}\right) \delta=8.26(\mathrm{~s}, 2 \mathrm{H}), 8.10(\mathrm{AB}, J=$ $8.0 \mathrm{~Hz}, 4 \mathrm{H}), 8.05(\mathrm{~s}, 2 \mathrm{H}), 7.06(\mathrm{~s}, 4 \mathrm{H}), 3.97(\mathrm{t}, J=$ $4.0 \mathrm{~Hz}, 4 \mathrm{H}), 3.87(\mathrm{t}, J=4.0 \mathrm{~Hz}, 4 \mathrm{H}), 1.80(\mathrm{~m}, 8 \mathrm{H}), 1.24$ $(\mathrm{m}, 56 \mathrm{H}), 0.87(\mathrm{~m}, 12 \mathrm{H}) ;{ }^{13} \mathrm{C} \mathrm{NMR}\left(100 \mathrm{MHz}, \mathrm{CDCl}_{3}\right)$ : 149.4, 148.7, 132.0, 130.6, 127.7, 127.3, 126.5, 124.1, 122.8, 118.3, 110.1, 117.0, 115.3, 97.1, 91.7, 82.9, 78.3, 69.1, 31.9, 29.7, 29.7, 29.6, 29.5, 29.4, 29.2, 26.0, 22.7, 14.1; MALDI-TOF MS $\left(\mathrm{C}_{76} \mathrm{H}_{96} \mathrm{O}_{4}\right): 1074\left[\mathrm{M}^{+}\right]$.

2.2b Dehydrobenzoannulene 1b: Yield 12\% (0.02 g, $0.01 \mathrm{mmol}$ from $0.16 \mathrm{~g}, 0.13 \mathrm{mmol}$ of $4 \mathbf{b}$ ), yellow colour solid, $\mathrm{mp} 72-74^{\circ} \mathrm{C}$, IR (neat): 2960, 2922, 
2852, 2372, 2339, 1592, 1506, 1466, 1249, $1206 \mathrm{~cm}^{-1}$; UV-Vis $\left(\mathrm{CH}_{2} \mathrm{Cl}_{2}\right) \lambda_{\max }(\log \varepsilon) 450$ (4.40), 425 (4.30), 410 (4.39), 371 (5.16), 307 (4.73), 295 (4.63) nm; ${ }^{1} \mathrm{H}$ NMR $\left(400 \mathrm{MHz}, \mathrm{CDCl}_{3}\right) \delta=8.61(\mathrm{~s}, 2 \mathrm{H}), 8.32$ $(\mathrm{AB}, J=8.0 \mathrm{~Hz}, 4 \mathrm{H}), 8.26(\mathrm{~s}, 2 \mathrm{H}), 4.09(\mathrm{~m}, 8 \mathrm{H})$, $1.90(\mathrm{~m}, 8 \mathrm{H}), 1.25(\mathrm{~m}, 72 \mathrm{H}), 0.86(\mathrm{~m}, 12 \mathrm{H}) ;{ }^{13} \mathrm{C} \mathrm{NMR}$ $\left(100 \mathrm{MHz}, \mathrm{CDCl}_{3}\right): 148.6,148.2,130.9,130.3,128.7$, $126.8,125.8,123.9,118.5,117.6,116.4,115.8,114.9$, $93.4,90.2,82.2,78.8,68.3,52.3,30.9,28.7,28.6$, $28.6,28.5,28.4,28.3,28.2,28.1,25.0,21.6,13.1$; MALDI-TOF MS $\left(\mathrm{C}_{84} \mathrm{H}_{112} \mathrm{O}_{4}\right): 1187\left[\mathrm{M}^{+}\right]$.

2.2c Dehydrobenzoannulene 1c: Yield 8\% (0.02 g, $0.01 \mathrm{mmol}$ from $0.19 \mathrm{~g}, 0.13 \mathrm{mmol}$ of $4 \mathbf{c}$ ), yellow colour solid, mp 74-76 ${ }^{\circ} \mathrm{C}$, IR (neat): 2960, 2922, 2852, 2372, 2339, 1592, 1506, 1466, 1249, $1206 \mathrm{~cm}^{-1}$; UVVis $\left(\mathrm{CH}_{2} \mathrm{Cl}_{2}\right) \lambda_{\max }(\log \varepsilon) 450$ (4.25), 425 (4.16), 410 (4.25), 370 (5.01), 310 (4.55), 295 (4.49) nm; ${ }^{1} \mathrm{H} \mathrm{NMR}\left(400 \mathrm{MHz}, \mathrm{CDCl}_{3}\right) \delta=8.59$ (s, 2H), 8.27 (q, $J=8.0 \mathrm{~Hz}, 4 \mathrm{H}), 8.20(\mathrm{~s}, 2 \mathrm{H}), 7.25(\mathrm{~s}, 2 \mathrm{H}), 7.33(\mathrm{~s}$, 2H), $4.04(\mathrm{~m}, 8 \mathrm{H}), 1.85(\mathrm{~m}, 8 \mathrm{H}), 1.19(\mathrm{~m}, 104 \mathrm{H}), 0.78$ $(\mathrm{m}, 12 \mathrm{H}) ;{ }^{13} \mathrm{C}$ NMR $\left(100 \mathrm{MHz}, \mathrm{CDCl}_{3}\right): 149.9,149.1$, 132.4, 131.0, 127.9, 127.5, 126.9, 124.6, 123.3, 118.8, 118.5, 118.4, 117.2, 115.7, 97.3, 91.9, 83.2, 78.4, 69.4, 32.1, 29.9, 29.8, 29.6, 29.5, 29.3, 29.2, 26.2, 22.8, 14.3; MALDI-TOF MS $\left(\mathrm{C}_{100} \mathrm{H}_{144} \mathrm{O}_{4}\right): 1408\left[\mathrm{M}^{+}\right]$.

\section{2d 1,8-Bis(2-formyl-5-t-butylphenylethynyl)pyrene}

(6): A Schlenk flask was charged with 2-bromo-4- $t$ butylbenzaldehyde (5) (2.2 g, $9.2 \mathrm{mmol}), \mathrm{Pd}\left(\mathrm{PPh}_{3}\right)_{2} \mathrm{Cl}_{2}$ $(0.26 \mathrm{~g}, 0.37 \mathrm{mmol}), \mathrm{PPh}_{3}(0.19 \mathrm{~g}, 0.8 \mathrm{mmol}), \mathrm{CuI}$ $(0.14 \mathrm{~g}, 0.8 \mathrm{mmol})$ and degassed $\mathrm{Et}_{3} \mathrm{~N}(50 \mathrm{~mL})$. The mixture was stirred at room temperature (rt) for $15 \mathrm{~min}$ and solid 1,8-diethynylpyrene (2) $(1.0 \mathrm{~g}, 4.0 \mathrm{mmol})$ was added. Stirring was continued at $55^{\circ} \mathrm{C}$ for $3 \mathrm{~h}$. The reaction mixture was cooled to room temperature and filtered. The filtrate was neutralized with $5 \%$ aqueous $\mathrm{HCl}$ and extracted with $\mathrm{CH}_{2} \mathrm{Cl}_{2}(50 \mathrm{~mL})$. The organic layer was washed with water $(2 \times 30 \mathrm{~mL})$ and dried over $\mathrm{Na}_{2} \mathrm{SO}_{4}$ and then solvent was removed. The crude product was purified by column chromatography on silica gel using $\mathrm{CH}_{2} \mathrm{Cl}_{2}$-hexane $(20: 80 \mathrm{v} / \mathrm{v})$ to yield 6 $(1.92 \mathrm{~g}, 84 \%)$ as a yellow solid. Mp $228-230^{\circ} \mathrm{C}$, IR (neat): v $2195(\mathrm{C} \equiv \mathrm{C}), 1693(\mathrm{C}=\mathrm{O}) \mathrm{cm}^{-1},{ }^{1} \mathrm{H}$ NMR $\left(400 \mathrm{MHz}, \mathrm{CDCl}_{3}\right): \delta 10.81$ (s, 2H), 8.80 (s, 2H), 8.28 (AB quartet, $J=8.0 \mathrm{~Hz}, 2 \mathrm{H}$ ), 8.19 (AB quartet, $J=$ $8.0 \mathrm{~Hz}, 2 \mathrm{H}), 8.12(\mathrm{~s}, 2 \mathrm{H}), 7.97(\mathrm{~d}, J=8.0 \mathrm{~Hz}, 2 \mathrm{H})$, $7.84(\mathrm{~d}, J=1.6 \mathrm{~Hz}, 2 \mathrm{H}), 7.57(\mathrm{dd}, J=8.0,1.6 \mathrm{~Hz}$, $2 \mathrm{H}), 1.43$ (s, 18H) ppm, ${ }^{13} \mathrm{C} \mathrm{NMR}\left(100 \mathrm{MHz}, \mathrm{CDCl}_{3}\right)$ : $\delta$ 191.6, 158.2, 133.9, 132.2, 132.0, 130.6, 128.7, $128.5,128.0,126.9,126.8,126.6,125.6,124.4,118.1$,
94.8, 92.1, 35.6, $31.3 \mathrm{ppm}, \mathrm{MS}(70 \mathrm{eV}, \mathrm{EI}): m / z(\%)=$ $570(100)\left[\mathrm{M}^{+}\right], 277(20)$.

2.2e 1,8-Bis((2-(2,2-dibromovinyl)-5-t-butylphenyl) ethynyl)pyrene (7): To a solution of $\mathrm{PPh}_{3}(1.84 \mathrm{~g}$, $7.0 \mathrm{mmol})$ in dry $\mathrm{CH}_{2} \mathrm{Cl}_{2}(35 \mathrm{~mL})$ powdered zinc $(0.5 \mathrm{~g}$, $7.0 \mathrm{mmol})$ was added and cooled to $0^{\circ} \mathrm{C} . \mathrm{CBr}_{4}(2.33 \mathrm{~g}$, $7.0 \mathrm{mmol}$ ) was added in small portions over $30 \mathrm{~min}$. The reaction mixture was brought to $\mathrm{rt}$ and continued the stirring for $1 \mathrm{~h}$. It was again cooled to $0^{\circ} \mathrm{C}$ and $6(0.5 \mathrm{~g}, 0.9 \mathrm{mmol})$ was added in small portions over $30 \mathrm{~min}$. Stirring was continued at rt for $8 \mathrm{~h}$. The reaction mixture was filtered and solvent was evaporated to dryness. The crude product was purified by column chromatography on a silica gel using hexane to yield $7(0.66 \mathrm{~g}, 85 \%)$ as a pale yellow solid. Mp $165^{\circ} \mathrm{C}$ (dec), IR (neat): $v 2210(\mathrm{C} \equiv \mathrm{C}) \mathrm{cm}^{-1},{ }^{1} \mathrm{H}$ NMR $\left(400 \mathrm{MHz}, \mathrm{CDCl}_{3}\right): \delta 8.79$ (s, 2H), 8.22 (AB quartet, $J=7.84 \mathrm{~Hz}, 2 \mathrm{H}), 8.14$ (AB quartet, $J=8.08 \mathrm{~Hz}$, $2 \mathrm{H}), 8.08$ (s, 2H), 8.06 (s, 2H), 7.81 (d, $J=8.3,2 \mathrm{H})$, $7.74(\mathrm{~d}, J=2.0 \mathrm{~Hz}, 2 \mathrm{H}), 7.45(\mathrm{dd}, J=8.3,2.0 \mathrm{~Hz}$, $2 \mathrm{H}), 1.4(\mathrm{~s}, 18 \mathrm{H}) \mathrm{ppm},{ }^{13} \mathrm{C} \mathrm{NMR}\left(100 \mathrm{MHz}, \mathrm{CDCl}_{3}\right)$ : $\delta 151.7,135.9,134.5,131.9,131.5,130.6,129.1,128.1$, 127.6, 126.8, 125.6, 124.9, 124.2, 122.6, 118.3, 94.0, 93.6, 91.1, 34.8, $31.1 \mathrm{ppm}$, MS (70 eV, EI): $m / z(\%)=$ 878 (13), 880 (52), 882 (80), 884 (52), 886 (13) [Br isotope peaks, $\mathrm{M}^{+}$], 800 (20), 802 (60), 804 (60), 806 (20) [M+-Br], 720 (10), 722 (20), 724 (10) [M+-2Br].

$2.2 \mathrm{f}$ 1,8-Bis((2-ethynyl-5-t-butylphenyl)ethynyl)pyrene (8): An oven dried Schlenk flask was charged with $7(0.4 \mathrm{~g}, 0.45 \mathrm{mmol})$ and dry hexane/toluene $(2: 1 \mathrm{v} / \mathrm{v}, 30 \mathrm{~mL})$ and cooled to $-50^{\circ} \mathrm{C} . n-\mathrm{BuLi}$ $(1.6 \mathrm{M}$ in hexane, $2.26 \mathrm{~mL}, 3.63 \mathrm{mmol}$ ) was added with stirring. After stirring at $-50^{\circ} \mathrm{C}$ for $30 \mathrm{~min}$ the reaction was complete. It was quenched with saturated $\mathrm{NH}_{4} \mathrm{Cl}$ at $-50^{\circ} \mathrm{C}$ extracted with $\mathrm{CH}_{2} \mathrm{Cl}_{2}$ $(30 \mathrm{~mL})$. The organic layer was washed with water $(2 \times 40 \mathrm{~mL})$, dried over $\mathrm{Na}_{2} \mathrm{SO}_{4}$ and then solvent was evaporated to dryness. The crude product was purified by column chromatography on silica gel using hexane to yield $8(0.22 \mathrm{~g}, 85 \%)$ as a pale yellow solid. $\mathrm{Mp}$ $178-180^{\circ} \mathrm{C}$ (dec), IR (neat): v $2200(\mathrm{C} \equiv \mathrm{C}) \mathrm{cm}^{-1}$, UVVis $\left(\mathrm{CH}_{2} \mathrm{Cl}_{2}\right): \lambda_{\text {max }}(\log \varepsilon) 432$ (4.72), 408 (4.72), 332 (4.89), 316 (4.72), 231 (5.01) nm, ${ }^{1} \mathrm{H}$ NMR (400 MHz, $\left.\mathrm{CDCl}_{3}\right): \delta 9.00(\mathrm{~s}, 2 \mathrm{H}), 8.23$ (AB quartet, $J=8.0 \mathrm{~Hz}$, $2 \mathrm{H}), 8.13$ (AB quartet, $J=8.0 \mathrm{~Hz}, 2 \mathrm{H}), 8.05(\mathrm{~s}, 2 \mathrm{H})$, $7.66(\mathrm{~d}, J=2.4 \mathrm{~Hz}, 2 \mathrm{H}), 7.65(\mathrm{~d}, J=7.6 \mathrm{~Hz}, 2 \mathrm{H})$, $7.0(\mathrm{dd}, J=8.2,2.0 \mathrm{~Hz}, 2 \mathrm{H}), 3.55(\mathrm{~s}, 2 \mathrm{H}), 1.39(\mathrm{~s}$, $18 \mathrm{H}) \mathrm{ppm},{ }^{13} \mathrm{C} \mathrm{NMR}\left(100 \mathrm{MHz}, \mathrm{CDCl}_{3}\right): \delta 151.6$, 132.0, 131.7, 131.4, 129.9, 129.8, 127.9, 126.8, 126.1, 
125.0, 124.1, 123.6, 118.6, 94.1, 92.0, 83.4, 80.8, 34.8, $31.0 \mathrm{ppm}$.

\section{2g Dehydrobenzoannulene 1d: $\mathrm{Cu}(\mathrm{OAc})_{2} \cdot \mathrm{H}_{2} \mathrm{O}$} $(0.14 \mathrm{~g}, 0.72 \mathrm{mmol})$ was dissolved in a mixture of acetonitrile and pyridine $(4: 1 \mathrm{v} / \mathrm{v}, 7.5 \mathrm{~mL})$ and $8(0.1 \mathrm{~g}$, $0.2 \mathrm{mmol}$ ) was added. The reaction mixture was stirred at $\mathrm{rt}$ for $4 \mathrm{~h}$. and then neutralized with $5 \%$ aqueous $\mathrm{HCl}$ followed by extraction with $\mathrm{CH}_{2} \mathrm{Cl}_{2}(20 \mathrm{~mL})$. The organic layer was washed with water $(30 \mathrm{~mL})$, dried over $\mathrm{Na}_{2} \mathrm{SO}_{4}$ and solvent was evaporated to dryness. The crude product was purified by column chromatography on silica gel using hexane to yield $1 \mathbf{d}(0.055 \mathrm{~g}$, $55 \%)$ as a yellow solid. $\mathrm{Mp}>290^{\circ} \mathrm{C}$, UV-Vis $\left(\mathrm{CH}_{2} \mathrm{Cl}_{2}\right)$ : $\lambda_{\max }(\log \varepsilon) 440$ (4.74), 414 (4.54), 401 (4.46), 353 (5.25), $304(4.96) \mathrm{nm}, \mathrm{IR}$ (neat): $v 2180(\mathrm{C} \equiv \mathrm{C}) \mathrm{cm}^{-1}$, ${ }^{1} \mathrm{H}$ NMR $\left(400 \mathrm{MHz}, \mathrm{CDCl}_{3}\right): \delta 8.87(\mathrm{~s}, 2 \mathrm{H}), 8.31$ (AB quartet, $J=8.0 \mathrm{~Hz}, 2 \mathrm{H}$ ), 8.24 (AB quartet, $J=8.0 \mathrm{~Hz}, 2 \mathrm{H}), 8.20(\mathrm{~s}, 2 \mathrm{H}), 7.88(\mathrm{~d}, J=8.4 \mathrm{~Hz}$, $2 \mathrm{H}), 7.86(\mathrm{~d}, J=1.9 \mathrm{~Hz}, 2 \mathrm{H}), 7.49(\mathrm{dd}, J=8.4$, $1.9 \mathrm{~Hz}, 2 \mathrm{H}), 1.43(\mathrm{~s}, 18 \mathrm{H}) \mathrm{ppm},{ }^{13} \mathrm{C}$ NMR $(100 \mathrm{MHz}$, $\left.\mathrm{CDCl}_{3}\right): \delta 152.5,135.5,132.8,131.3,129.2,128.1$, 127.8, 127.2, 125.4, 125.1, 124.6, 123.4, 121.5, 118.4, 97.4, 92.7, 82.9, 79.1, 35.1, $31.1 \mathrm{ppm}$, MS (70 eV, EI): $m / z(\%)=560(100)\left[\mathrm{M}^{+}\right]$, HRMS: Calcd. for $\mathrm{C}_{44} \mathrm{H}_{34}$ 560.25043 ; found 560.24924 .

2.2h 1,3,6,8-Tetrakis((2-ethynylphenyl)ethynyl)pyrene (14): A red solution of $13(0.5 \mathrm{~g}, 0.5 \mathrm{mmol})$ in degassed THF $(25 \mathrm{~mL})$ was treated with $n-\mathrm{Bu}_{4} \mathrm{NF}$ $(0.013 \mathrm{~g}, 0.05 \mathrm{mmol})$ and the resulting mixture was stirred at $\mathrm{rt}$ for $15 \mathrm{~min}$. The reaction mixture was then poured into ice cold water $(100 \mathrm{~mL})$ and the red colour solid was filtered and repeatedly washed with water $(2 \times 100 \mathrm{~mL})$ and dried. Due to its poor solubility NMR of 14 could not be obtained. Yield: $0.33 \mathrm{~g}$ (95\%), IR (neat): $v 2196(\mathrm{C} \equiv \mathrm{C}) \mathrm{cm}^{-1}$, MALDI-TOF MS: $\mathrm{m} / z$ $698\left[\mathrm{C}_{56} \mathrm{H}_{26}, \mathrm{M}^{+}\right]$.

\section{$2.2 \mathrm{i}$ Bis-dehydrobenzoannulene 9: $\mathrm{Cu}(\mathrm{OAc})_{2} \cdot \mathrm{H}_{2} \mathrm{O}$} $(0.23 \mathrm{~g}, 1.15 \mathrm{mmol})$ was dissolved in a mixture of pyridine and ether $(3: 1 \mathrm{v} / \mathrm{v}, 100 \mathrm{~mL})$. Compound $\mathbf{1 4}$ $(0.1 \mathrm{~g}, 0.15 \mathrm{mmol})$ was finely suspended in $20 \mathrm{~mL}$ of pyridine/ether $(3: 1 \mathrm{v} / \mathrm{v})$ and added to the reaction mixture using a dropping funnel over $3 \mathrm{~h}$ with continuous stirring at rt. After complete addition, the reaction mixture was stirred at $\mathrm{rt}$ for $24 \mathrm{~h}$. The red solid precipitated during course of the reaction was filtered and washed with dil $\mathrm{HCl}(50 \mathrm{~mL})$. The solid obtained was completely insoluble and hence solution characterization could not be done. DBA 9 (0.10 g, 10\%), IR (neat): $v 2185$ ( $v \mathrm{C} \equiv \mathrm{C}) \mathrm{cm}-1$, MALDI-TOF MS $: m / z=694$ $\left[\mathrm{M}+, \mathrm{C}_{56} \mathrm{H}_{22}\right], 1388\left(2 \mathrm{M}^{+}, \pi\right.$-dimer $)$.

$2.2 \mathrm{j}$ 1,3,6,8-Tetrakis(2-formyl-5-t-butylphenylethynyl) pyrene (14): A mixture of $5(0.40 \mathrm{~g}, 1.67 \mathrm{mmol})$, $\mathrm{Pd}\left(\mathrm{PPh}_{3}\right)_{4} \quad(0.077 \mathrm{~g}, \quad 0.067 \mathrm{mmol}), \quad \mathrm{CuI} \quad(0.025 \mathrm{~g}$, $0.13 \mathrm{mmol})$ and $\mathrm{Et}_{3} \mathrm{~N}(8.0 \mathrm{~mL})$ was stirred at room temperature for $15 \mathrm{~min}$. 1,3,6,8-tetraethynylpyrene (12) $(0.1 \mathrm{~g}, 0.33 \mathrm{mmol})$ was added and stirring was continued at $50^{\circ} \mathrm{C}$ for $4 \mathrm{~h}$ during which the reaction mixture turned orange red. Solvent was removed under reduced pressure and the crude product was purified by column chromatography on silica gel and eluted with a mixture of $\mathrm{CH}_{2} \mathrm{Cl}_{2}$ and hexane $(1: 2 \mathrm{v} / \mathrm{v})$ to yield tetraaldehyde $15(0.25 \mathrm{~g}, 81 \%)$ as an orange red fluorescent solid. Mp $210^{\circ} \mathrm{C}$ (dec), IR (neat): v $1683(\mathrm{C}=\mathrm{O}), 2190(\mathrm{C} \equiv \mathrm{C}) \mathrm{cm}^{-1},{ }^{1} \mathrm{H} \mathrm{NMR}(400 \mathrm{MHz}$, $\left.\mathrm{CDCl}_{3}\right): \delta 10.77(\mathrm{~s}, 4 \mathrm{H}), 8.78(\mathrm{~s}, 4 \mathrm{H}), 8.52(\mathrm{~s}, 2 \mathrm{H})$, $7.92(\mathrm{~d}, J=8.4,4 \mathrm{H}), 7.85(\mathrm{~d}, \mathrm{~J}=1.6 \mathrm{~Hz}, 4 \mathrm{H})$, $7.56(\mathrm{dd}, J=8.4,1.6 \mathrm{~Hz}, 4 \mathrm{H}) 1.45(\mathrm{~s}, 36 \mathrm{H}) \mathrm{ppm}$, ${ }^{13} \mathrm{C}$ NMR $\left(100 \mathrm{MHz}, \mathrm{CDCl}_{3}\right): \delta 190.5,158.0,135.3$, $134.2,132.3,130.0,129.7,128.5,127.8,126.6,125.8$, $118.8,93.3,92.9,35.4,31.0 \mathrm{ppm}, \mathrm{MS}(70 \mathrm{eV}, \mathrm{EI}): \mathrm{m} / \mathrm{z}$ $(\%)=938(35 \%)\left[\mathrm{M}^{+}\right], 920(40), 882$ (95), 854 (100), 826 (90).

2.2k 1,3,6,8-Tetrakis((2-(2,2-dibromovinyl)-5-t-butylphenyl)ethynyl)pyrene (16): A mixture of $\mathbf{1 5}(1.0 \mathrm{~g}$, $1.0 \mathrm{mmol}), \mathrm{CBr}_{4}(5.67 \mathrm{~g}, 17.0 \mathrm{mmol})$ and $\mathrm{PPh}_{3}(4.5 \mathrm{~g}$, $17.0 \mathrm{mmol}$ ) in $60 \mathrm{~mL}$ of benzene was refluxed for $8 \mathrm{~h}$. The reaction mixture was brought to room temperature and filtered and the filtrate was passed through a short pad of silica gel using benzene as an eluent. Solvent was evaporated to dryness and the solid obtained was washed with excess of acetone to get pure $16(0.9 \mathrm{~g}$, $55 \%)$ as an orange red solid. $\mathrm{Mp} 262^{\circ} \mathrm{C}(\mathrm{dec})$, IR (neat): v $2195(\mathrm{C} \equiv \mathrm{C}) \mathrm{cm}^{-1}$, UV-Vis $\left(\mathrm{CH}_{2} \mathrm{Cl}_{2}\right): \lambda_{\max }$ $(\log \varepsilon) 482$ (4.81), 453 (4.69), 353 (4.92) 250 (5.01) $\mathrm{nm},{ }^{1} \mathrm{H}$ NMR $\left(400 \mathrm{MHz}, \mathrm{CDCl}_{3}\right): \delta 8.79(\mathrm{~s}, 4 \mathrm{H}), 8.47$ (s, 2H), 8.07 (s, 4H), $7.80(\mathrm{~d}, J=8.3 \mathrm{~Hz}, 4 \mathrm{H}), 7.75$ (d, $J=1.9 \mathrm{~Hz}, 4 \mathrm{H}), 7.47(\mathrm{dd}, J=8.3,1.9 \mathrm{~Hz}, 4 \mathrm{H}), 1.41$ $(\mathrm{s}, 36 \mathrm{H}) \mathrm{ppm},{ }^{13} \mathrm{C}$ NMR $\left(100 \mathrm{MHz}, \mathrm{CDCl}_{3}\right): \delta 151.9$, 136.0, 134.9, 134.0, 132.7, 132.1, 129.4, 128.0, 127.5, $125.9,122.5,119.1,94.9,92.7,91.4,34.9,31.2 \mathrm{ppm}$.

2.21 1,3,6,8-Tetrakis((2,6-bis(2,2-dibromovinyl)-4-tbutylphenyl)ethynyl)pyrene(19): To a solution of $\mathrm{PPh}_{3}$ $(2.4 \mathrm{~g}, 9.14 \mathrm{mmol})$ in dry $\mathrm{CH}_{2} \mathrm{Cl}_{2}(50 \mathrm{~mL})$ powdered zinc $(0.6 \mathrm{~g}, 9.14 \mathrm{mmol})$ was added and the mixture was cooled to $0^{\circ} \mathrm{C} . \mathrm{CBr}_{4}(3.03 \mathrm{~g}, 9.14 \mathrm{mmol})$ was added portion-wise over $30 \mathrm{~min}$. The reaction mixture was 
brought to rt and stirring was continued for $1 \mathrm{~h}$. It was cooled to $0^{\circ} \mathrm{C}$ and $18(0.3 \mathrm{~g}, 0.3 \mathrm{mmol})$ was added portion-wise over $30 \mathrm{~min}$. Stirring was continued at $\mathrm{rt}$ for $12 \mathrm{~h}$. Reaction mixture was filtered and then solvent was evaporated to dryness. The crude product was purified by column chromatography on silica gel using THF/hexane $(5: 95, \mathrm{v} / \mathrm{v})$ as eluent to yield $\mathbf{1 9}$ as a red solid. Yield 60\%; Mp: $245^{\circ} \mathrm{C}$ (decomp), IR (neat): $v$ $2220(\mathrm{C} \equiv \mathrm{C}) \mathrm{cm}^{-1}$, UV-Vis $\left(\mathrm{CH}_{2} \mathrm{Cl}_{2}\right): \lambda_{\max }(\log \varepsilon) 460$ (4.94), 360 (5.10), 254 (5.44) nm, ${ }^{1} \mathrm{H}$ NMR (400 MHz, $\left.\mathrm{CDCl}_{3}\right): \delta 8.81(\mathrm{~s}, 4 \mathrm{H}), 8.48(\mathrm{~s}, 2 \mathrm{H}), 8.07(\mathrm{~s}, 8 \mathrm{H})$, $7.85(\mathrm{~s}, 8 \mathrm{H}), 1.40(\mathrm{~s}, 36 \mathrm{H}) \mathrm{ppm},{ }^{13} \mathrm{C}$ NMR $(100 \mathrm{MHz}$, $\left.\mathrm{CDCl}_{3}\right): \delta 151.4,137.6,136.1,134.1,131.9,128.0$, $127.5,125.9,124.0,118.8,98.3,92.6,92.2,35.2$, $31.0 \mathrm{ppm}$.

\section{Results and discussion}

The structures of the DBAs (1a-d) with pyrene core, derived from 1,8-diethynylpyrene (2), are shown in scheme 1. DBAs 1a-c with long alkoxy chains were expected to exhibit discotic liquid crystalline behaviour ${ }^{16}$ and hence were investigated.

\subsection{Synthesis of DBA $1 a-c$}

Synthesis of DBAs (1a-c) bearing dialkoxy groups was accomplished by the Sonogashira coupling of $\mathbf{2}$ with 3a-c to yield $\mathbf{4 a - c}$. Iodides 3a-c were sluggish to undergo Sonogashira coupling and under the reaction conditions 2 polymerized to yield an insoluble red polymer which reduced the yields of the desired product $\mathbf{4 a - c . ~ I n ~ s i t u ~ d e p r o t e c t i o n ~ o f ~ t h e ~ s i l y l ~ g r o u p ~ i n ~} \mathbf{4 a - c}$

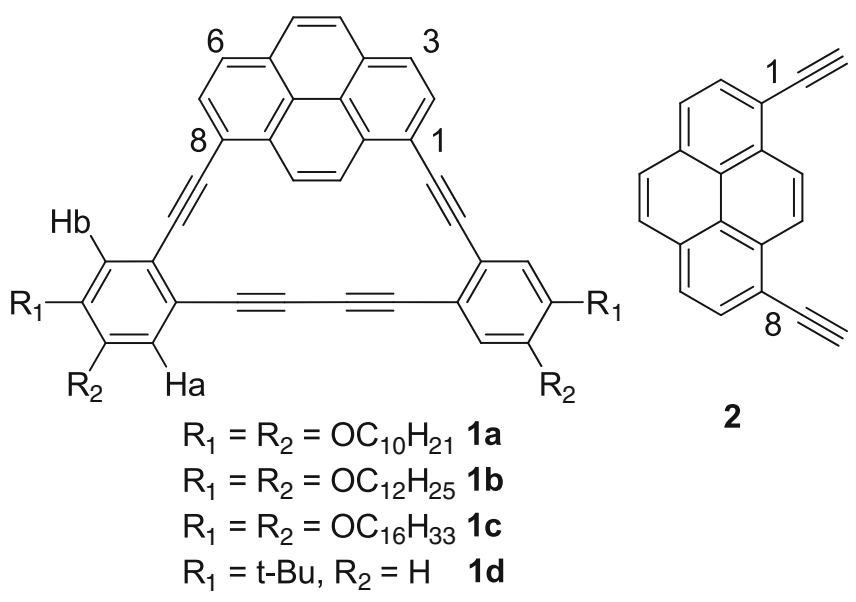

Scheme 1. Structure of DBAs (1a-d) synthesized from 1,8-diethynylpyrene (2)(systematic numbering of the pyrene ring is shown). followed by oxidative coupling of the resulting terminal acetylenes using $\mathrm{Cu}(\mathrm{OAc})_{2}$ and pyridine was carried out in one-pot to yield DBAs 1a-c (scheme 2).

\subsection{Synthesis of DBA $\mathbf{1 d}$}

Synthesis of 1d bearing tert-butyl group was accomplished following a slightly different route. Sonogashira coupling of diyne $\mathbf{2}$ with 2-bromo-4- $t$ butylbenzaldehyde (5) under standard conditions proceeded smoothly and gave the desired dialdeyhde $\mathbf{6}$ in $84 \%$ yield as an yellow fluorescent solid (scheme 3). In comparison to $\mathbf{3 a}-\mathbf{c}$ bromoaldehyde $\mathbf{5}$ underwent coupling in a facile manner and polymerization of $\mathbf{2}$ under these conditions was minimum and the desired coupling product was obtained in good yield. The aldehyde protons in 6 appeared as a singlet at $\delta 10.81 \mathrm{ppm}$ in the ${ }^{1} \mathrm{H}$ NMR spectrum. Dialdehyde $\mathbf{6}$ was converted to bisdibromovinyl derivative 7 by treating with $\mathrm{CBr}_{4}, \mathrm{Ph}_{3} \mathrm{P}$ and $\mathrm{Zn}$ in $\mathrm{DCM}$ in $85 \%$ yield. The vinylic protons in 7 appeared as a singlet at $\delta 8.06 \mathrm{ppm}$ in the ${ }^{1} \mathrm{H}$ NMR spectrum. Treatment of 7 with LDA in THF yielded the desired terminal acetylene 8 only in 10\% yield. However, treatment of $\mathbf{7}$ directly with $n$-BuLi in a mixture of hexane and toluene at $-50^{\circ} \mathrm{C}$ yielded diacetylene 8 in $85 \%$ as a pale yellow solid. The acetylenic protons appeared as a singlet at $\delta 3.55 \mathrm{ppm}$ in the ${ }^{1} \mathrm{H}$ NMR spectrum of $\mathbf{8}$. Oxidative cyclization of $\mathbf{8}$ using $\mathrm{Cu}(\mathrm{OAc})_{2}$ and pyridine gave DBA 1d in good yield as a yellow solid (scheme 3).

Pyrene protons, namely H-4/5 and H-9/10 appeared as singlets in $\mathbf{4 a - c , ~} \mathbf{8}$ and 1a-d. Peripheral protons $\mathrm{H}-$ $4 / 5$ in DBAs 1a-d were deshielded by about 0.15 to $0.22 \mathrm{ppm}$ when compared to the corresponding open precursors $\mathbf{4 a - c}$ and $\mathbf{8}$, respectively. Intraannular protons $\mathrm{H}-9 / 10$ in $\mathbf{1 a}-\mathbf{d}$ were shielded by about 0.13 to $0.26 \mathrm{ppm}$ when compared to that in $\mathbf{4 a - c}$ and $\mathbf{8}$, respectively. Similarly, peripheral protons on the phenyl rings, namely $\mathrm{Ha}$ and $\mathrm{Hb}$ (scheme 1), were deshielded in DBAs 1a-d compared to those in open precursors 4a-c and 8. (table 1). These observations are consistent with 1a-d being a closed loop of $\pi$-electrons in comparison to $\mathbf{4 a - c}$ and $\mathbf{8}$. Compounds $\mathbf{1 a - d}$ can be considered either as a dehydrobenzo[22]annulene or a dehydrobenzo[18]- annulene, depending upon how the $\pi$-electrons are counted on the pyrene ring.

While 1d is a high melting solid, compounds 1a-c are low melting due to the presence of long flexible alkoxy chains. In fact, $\mathbf{1 b}$ and $\mathbf{1 c}$ are waxy solids. Structures 1a-c are isosceles trapezoid shaped that possess a planar pyrene ring that is part of the rigid DBA ring bearing long alkoxy chains. It was expected that 

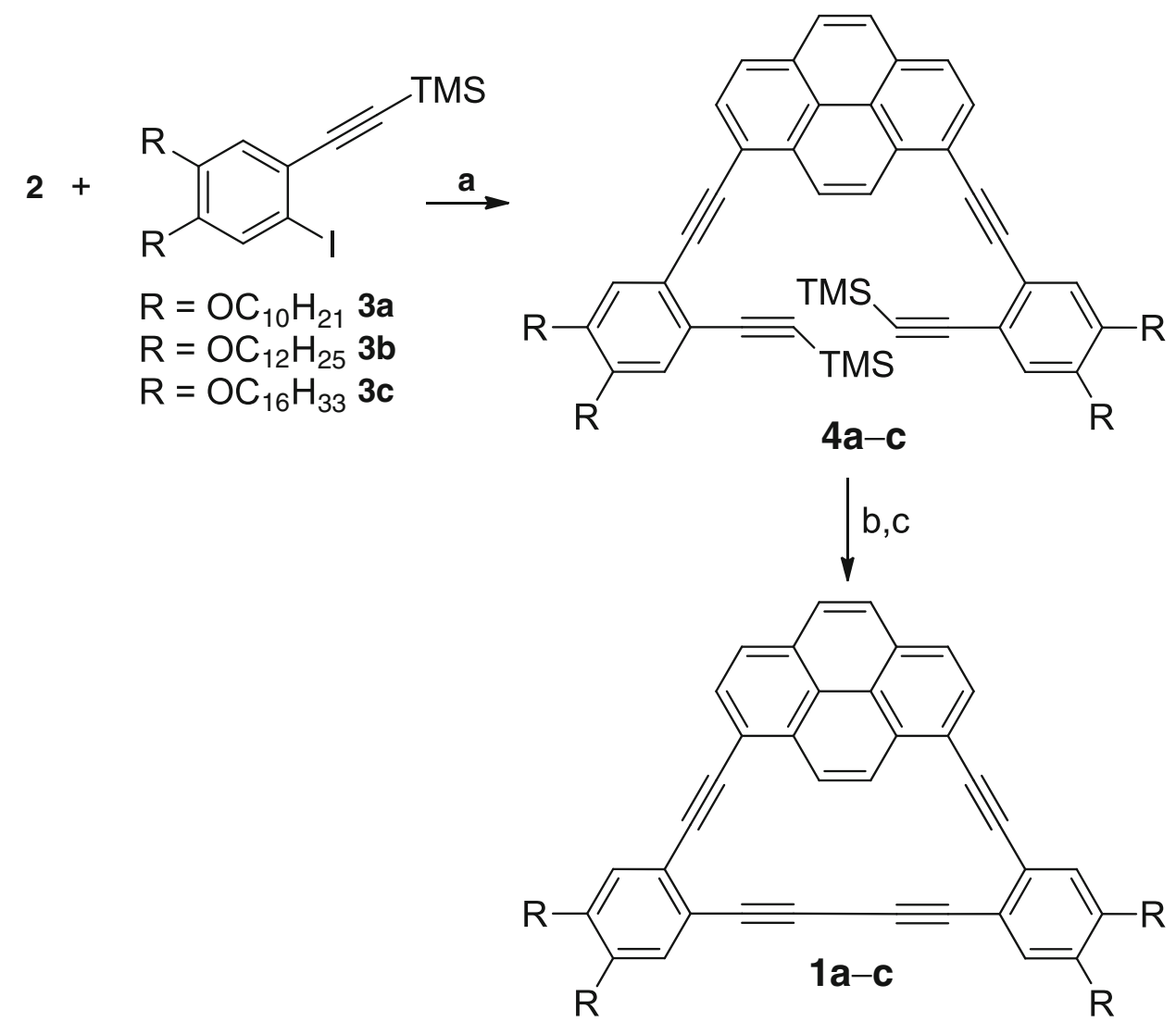

Scheme 2. Synthesis of DBAs 1a-c. Reagents and reaction conditions: (a) $\mathrm{Pd}\left(\mathrm{PPh}_{3}\right)_{2} \mathrm{Cl}_{2}, \mathrm{Ph}_{3} \mathrm{P}, \mathrm{CuI}, i$ - $\mathrm{Pr}_{3} \mathrm{~N}, 50^{\circ} \mathrm{C}, 4-6 \mathrm{~h}, \mathbf{4 a} 22 \%, 4 \mathbf{b} 19 \%, 4 \mathbf{c} 18 \%$; (b) TBAF, THF, rt, 1 h; (c) $\mathrm{Cu}(\mathrm{OAc})_{2}$, py, $\mathrm{CH}_{3} \mathrm{CN}, \mathrm{rt}, 12 \mathrm{~h}, \mathbf{1 a} 10 \%, \mathbf{1 b} 8 \%, \mathbf{1 c} 8 \%$.
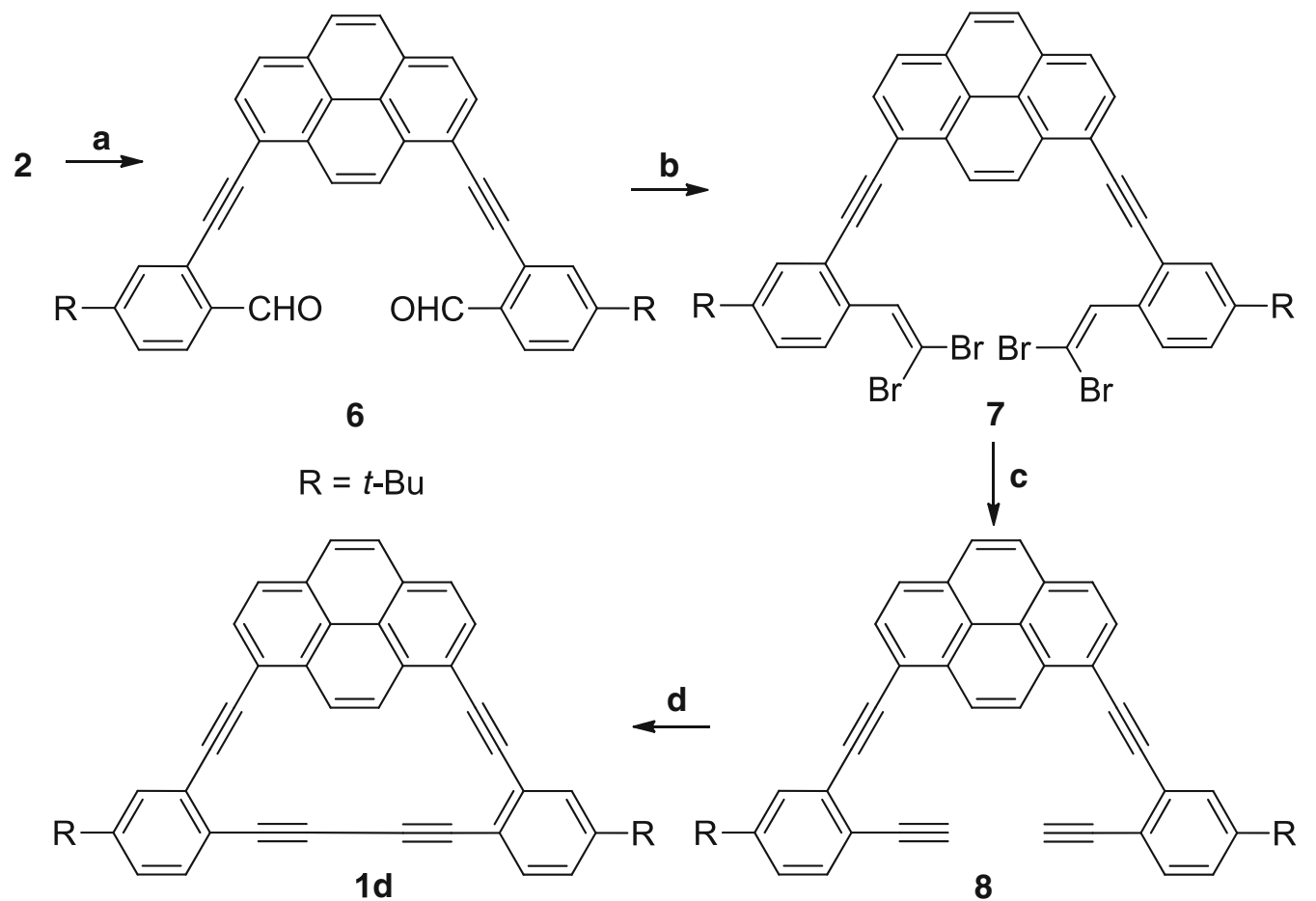

Scheme 3. Synthesis of DBA 1d. Reagents and reaction conditions: (a) 2-bromo-4-tbutylbenzaldehyde (5), $\mathrm{Pd}\left(\mathrm{PPh}_{3}\right)_{2} \mathrm{Cl}_{2}, \mathrm{Ph}_{3} \mathrm{P}, \mathrm{CuI}, \mathrm{Et}_{3} \mathrm{~N}, 55^{\circ} \mathrm{C}, 3 \mathrm{~h}, 84 \%$; (b) $\mathrm{CBr}_{4}, \mathrm{Ph}_{3} \mathrm{P}, \mathrm{Zn}$, $\mathrm{CH}_{2} \mathrm{Cl}_{2}, \mathrm{rt}, 8 \mathrm{~h}, 85 \%$; (c) $n$-BuLi, hexane/toluene, $-50^{\circ} \mathrm{C}, 30 \mathrm{~min}, 85 \%$; (d) $\mathrm{Cu}(\mathrm{OAc})_{2}$, py, $\mathrm{CH}_{3} \mathrm{CN}, \mathrm{rt}, 4 \mathrm{~h}, 55 \%$. 
Table 1. Comparison of chemical shift $\left(\delta_{\mathrm{H}}\right)$ values of various protons of DBAs $(\mathbf{1 a - d})$ with their open precursors $(\mathbf{4 a}-\mathbf{c}$ and $\mathbf{8})$.

\begin{tabular}{lllllllll}
\hline & $\mathbf{1 a}$ & $\mathbf{4 a}$ & $\mathbf{1 b}$ & $\mathbf{4 b}$ & $\mathbf{1 c}$ & $\mathbf{4 c}$ & $\mathbf{1 d}$ & $\mathbf{8}$ \\
\hline $\mathrm{H} 4 / 5$ & 8.06 & 8.02 & 8.26 & 8.06 & 8.28 & 8.06 & 8.20 & 8.05 \\
$\mathrm{H} 9 / 10$ & 8.28 & 8.93 & 8.62 & 8.88 & 8.66 & 8.87 & 8.87 & 9.0 \\
$\mathrm{Ha}$ & 7.06 & 7.09 & 7.30 & 7.05 & 7.32 & 7.04 & 7.88 & 7.65 \\
$\mathrm{Hb}$ & 7.07 & 7.17 & 7.37 & 7.14 & 7.40 & 7.13 & 7.86 & 7.66 \\
\hline
\end{tabular}

such structural elements might impart discotic liquid crystalline properties to 1a-c. For example triphenylene derivatives bearing multiple long alkoxy chains are known to exhibit discotic liquid crystalline behaviour. ${ }^{14}$ However, examination of $\mathbf{1 a - c}$ using a polarizing optical microscope under both heating and cooling cycles did not exhibit any liquid crystalline state. These low melting solids melted to a clear liquid state on heating and turned to a cloudy pasty mass on cooling.

\subsection{Attempted synthesis of multiply bridged dehydrobenzoannulenes with pyrene core}

Having accomplished the synthesis of DBAs 1a-d we investigated the synthesis of multiply bridged DBAs 9-11 (scheme 4). It was envisaged that 1,3,6,8tetraethynylpyrene (12) could serve as the building block for the synthesis of DBAs 9-11.

\subsection{Synthesis of DBAs 9-11}

Precursor 13, whose synthesis has been described from our laboratory, ${ }^{17}$ was used for the synthesis of 9 . Treatment of 13 with $n$-Bu $\mathrm{Bu}_{4} \mathrm{NF}$ in THF yielded octaacetylene $\mathbf{1 4}$ in near quantitative yield as a red insoluble solid (scheme 5). It was characterized by MALDI-TOF MS which showed the molecular ion peak $\left(\mathrm{M}^{+}\right)$at $\mathrm{m} / \mathrm{z}$ 698. It was immediately subjected to oxidative cyclization under high dilution conditions using $\mathrm{Cu}(\mathrm{OAc})_{2}$ and pyridine in ether gave $\mathbf{9}$ as a red solid, albeit in poor yield. The solid was completely insoluble in all the common organic solvents which hampered its characterization in solution. However, MALDI-TOF MS clearly showed the molecular ion peak at m/z 694 along with another peak at $\mathrm{m} / \mathrm{z} 1388$, presumably due to the $\pi$-dimer of 9 .

In an effort to make a more soluble derivative of $\mathbf{9}$, target $\mathbf{1 0}$ was chosen with tertiarybutyl groups substituted around the periphery. Sonogashira coupling of 2-bromo-4- $t$-butylbenzaldehyde 5 with 1,3,6,8tetraethynylpyrene (12) gave the corresponding tetra coupled product $\mathbf{1 5}$ in $81 \%$ yield as an orange red fluorescent solid (scheme 6). The aldehyde protons appeared as a singlet at $\delta 10.77 \mathrm{ppm}$ and the pyrene protons appeared as two singlet at $\delta 8.78 \mathrm{ppm}(\mathrm{H}-4 / 5 / 9 / 10)$ and $8.52 \mathrm{ppm}(\mathrm{H}-2 / 7)$ in the integration ratio of $2: 2: 1$, respectively, which is consistent with the symmetry of the 1,3,6,8-tetra substituted derivative of pyrene. We have demonstrated earlier the successful utilization of Corey-Fuchs reaction for the conversion of polyaldehydes to the corresponding terminal alkynes in the

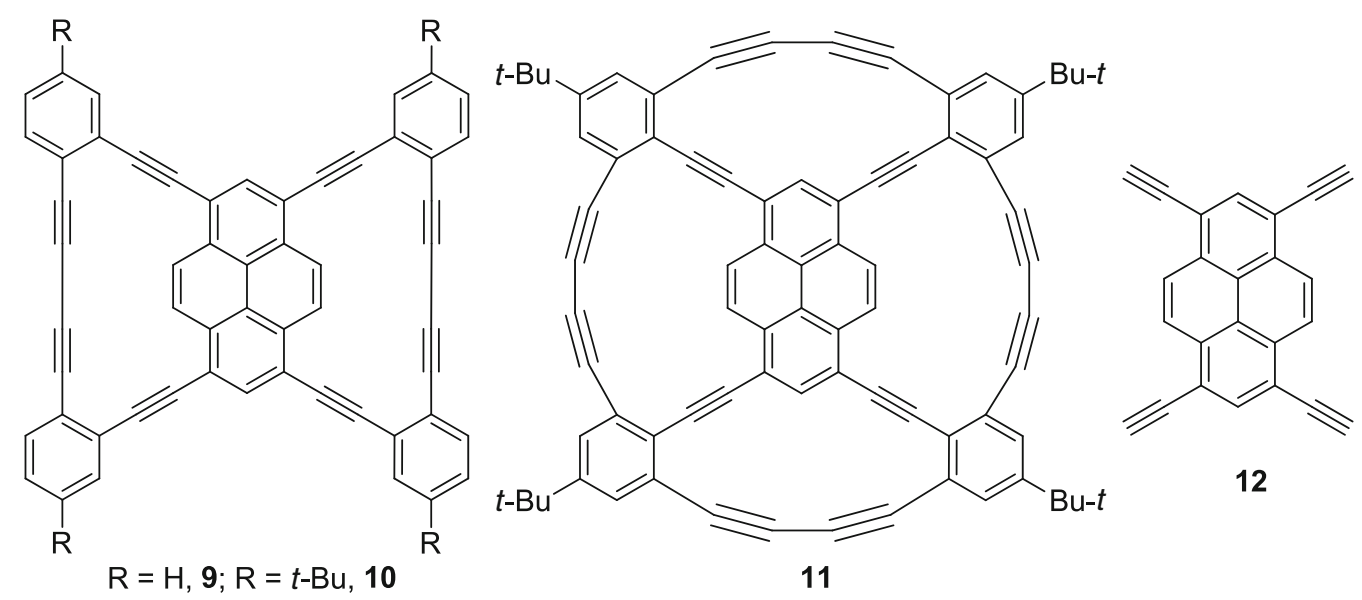

Scheme 4. Structure of multiply bridged DBAs 9-11 and 1,3,6,8-tetraethynylpyrene 12. 


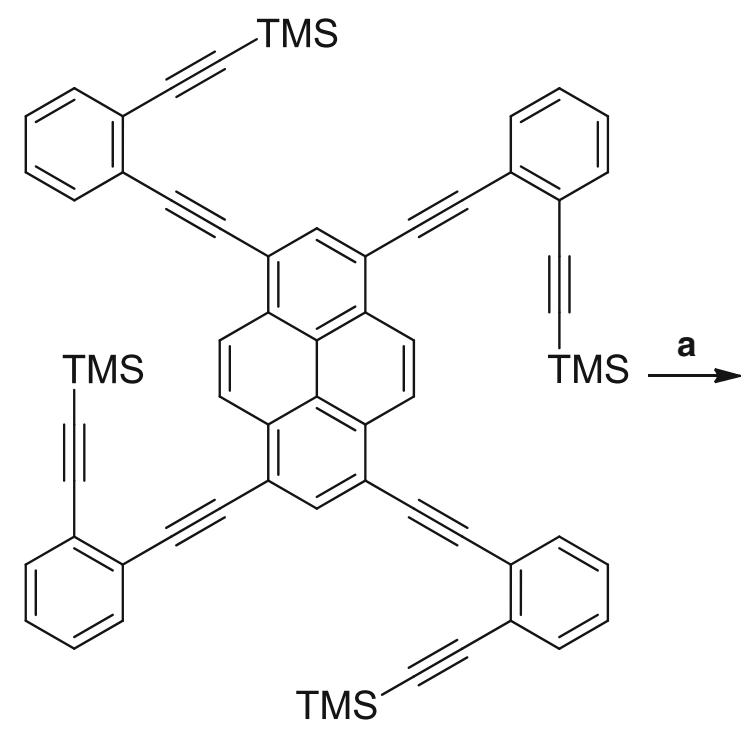<smiles>C#Cc1ccccc1C#Cc1cc(C#Cc2ccccc2C#C)c2ccc3c(C#Cc4ccccc4C#Cc4ccccc4)cc(C#Cc4ccccc4C#C)c4ccc1c2c43</smiles>

13

\section{4}<smiles>CC(C)(C)C</smiles>

Scheme 5. Synthesis of DBA 9. Reagents and reaction conditions: (a) $n-\mathrm{Bu}_{4} \mathrm{NF}$, THF, rt, 15 min, $95 \%$; (b) $\mathrm{Cu}(\mathrm{OAc})_{2}$, py, ether, rt, $24 \mathrm{~h}, 10 \%$.

synthesis of polyalkynes. ${ }^{18}$ In our experience the use of Bestmann-Ohira reagent, namely dimethyl (1-azo-2oxopropyl)phosphonate, for the conversion of polyaldehydes to polyalkynes gave only poor yields. Therefore, we used Corey-Fuchs methodology in the present study for the conversion of polyaldehyde precursors to poly terminal alkynes. Tetraaldehyde $\mathbf{1 5}$ was readily converted to the corresponding tetrakis(dibromovinyl) derivative 16 using $\mathrm{CBr}_{4}$, and $\mathrm{Ph}_{3} \mathrm{P}$ in $55 \%$ yield. The vinylic protons appeared as a singlet at $\delta 8.07$ along with two singlets due to the pyrene protons at 8.79 and $8.47 \mathrm{ppm}$ in the ${ }^{1} \mathrm{H}$ NMR spectrum of 16. Efforts to convert the octabromo derivative $\mathbf{1 6}$ to the corresponding tetraalkyne 17 failed. Part of the problem was the poor solubility of $\mathbf{1 6}$, especially at low temperatures. The reaction was tried with LDA and $n$-BuLi using various solvents and reaction conditions. All these attempts gave a fairly complicated mixture of products along with $\mathbf{1 7}$ due to incomplete elimination. Isolation of pure $\mathbf{1 7}$ from the mixture proved impractical.

In a similar manner we attempted the synthesis of the precursor to $\mathbf{2 0}$ from the readily available octaaldehyde derivative $\mathbf{1 8}$ which could be easily prepared in good yields from the Sonogashira coupling of $\mathbf{1 2}$ and 2-bromo-5-t-butylisophthalaldehyde (21), as described by our group earlier. ${ }^{15}$ The octakis(dibromovinyl) derivative 19 was obtained from octaaldehyde $\mathbf{1 8}$ in $60 \%$ yield as a red solid using $\mathrm{CBr}_{4}$ (scheme 7). The symmetrical tetra substitution pattern on the pyrene was confirmed by the observation of two singlets for the pyrene protons at $\delta 8.79$ and $8.47 \mathrm{ppm}$ in the $2: 1$ ratio in the ${ }^{1} \mathrm{H}$ NMR spectrum of 19. Once again, attempts to 


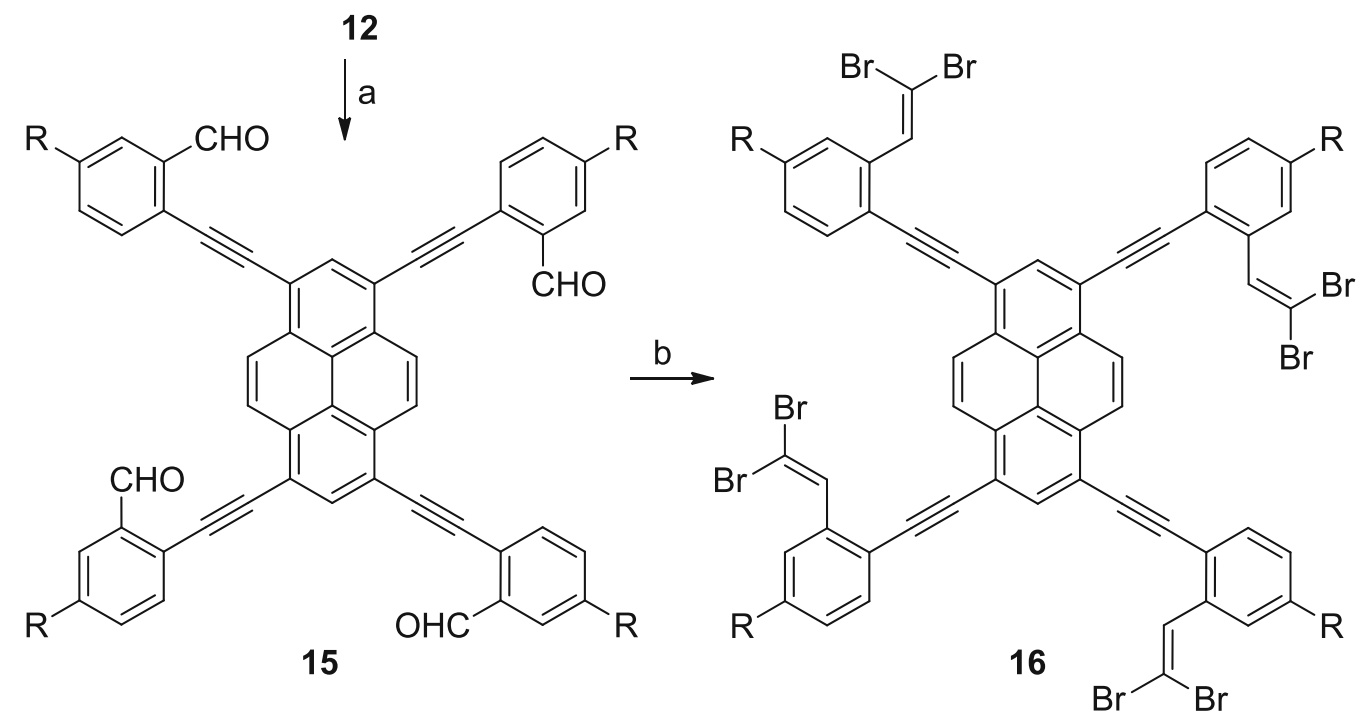<smiles>[R]c1ccc(C#Cc2cc(C#Cc3ccc([R])cc3C#C)c3ccc4c(C#Cc5ccc([R])cc5C#C)cc(C#Cc5ccc([R])cc5C#C)c5ccc2c3c54)c(C#C)c1</smiles>

17

Scheme 6. Attempted synthesis of precursor 17 to DBA 10. Reagents and reaction conditions: (a) 2-bromo-4-t -butylbenzaldehyde (5), $\mathrm{Pd}\left(\mathrm{PPh}_{3}\right)_{4}, \mathrm{CuI}, \mathrm{Et}_{3} \mathrm{~N}, 50^{\circ} \mathrm{C}, 4 \mathrm{~h}, 81 \%$; (b) $\mathrm{CBr}_{4}$, $\mathrm{Ph}_{3} \mathrm{P}$, benzene, reflux, $18 \mathrm{~h}, 55 \%$; (c) $n$-BuLi, hexane/toluene, $-50^{\circ} \mathrm{C}, 1 \mathrm{~h}$; (d) LDA, THF $-78^{\circ} \mathrm{C}$, $30 \mathrm{~min}$; (e) LDA, toluene/hexane, $-50^{\circ} \mathrm{C}, 1 \mathrm{~h}$.

convert 19 to 20 under various conditions failed. Therefore, the synthesis of targets $\mathbf{1 0}$ and $\mathbf{1 1}$ could not be accomplished using the present approach. DBA 11 is not a planar molecule. It must be emphasized that the challenge in the synthesis of target $\mathbf{1 1}$ is due to highly strained bowl-shaped structure of this molecule. Nevertheless, an attempt has been made to synthesize $\mathbf{1 1}$ that is described in this report.

\subsection{Absorption and fluorescence emission spectra of DBAs and their precursors}

Absorption spectrum of $\mathbf{2}$ showed vibrational fine structure that is typical of substituted pyrene derivatives and absorption is confined to the UV region. Extension of conjugation in $\mathbf{8}$ and $\mathbf{1 d}$ resulted in bathochromic shift by nearly $50 \mathrm{~nm}$ into the visible region. However, in 8 the vibrational fine structure is lost in comparison to $\mathbf{2}$ and the lowest energy absorption bands of $\mathbf{8}$ appeared broad. In comparison to $\mathbf{8}$, the absorption bands of $\mathbf{1 d}$ are further red shifted by about $10 \mathrm{~nm}$ and the bands are also sharper (figure 1). This might be due to the rigid nature of the dehydrobenzoannulene skeleton. Extension of conjugation of pyrene chromophore with alkynyl groups results in the shifting of the fluorescence emission to visible region. ${ }^{13,17}$ A comparison of the absorption and fluorescence spectra of $\mathbf{1 d}, \mathbf{2}$ and $\mathbf{8}$ clearly reveals that the absorption and emission maxima are shifted to longer wavelengths with increasing conjugation. Otherwise the features of the absorption and emission spectra in figures 1 and 2 are reminiscent of the spectra of ethynylpyrene derivatives reported earlier. ${ }^{13,17}$ Absorption and fluorescence emission spectra of $\mathbf{4 a - c}$ and 1a-c were similar to that of $\mathbf{8}$ and $\mathbf{1 d}$, respectively. 


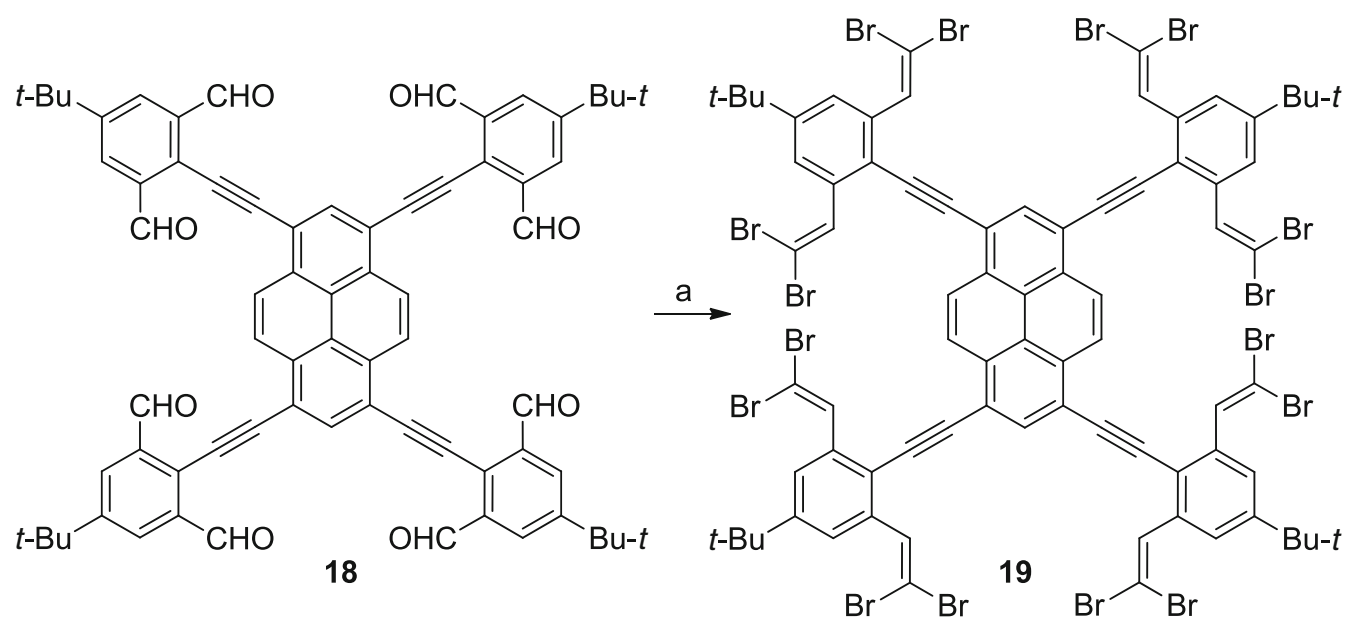<smiles>C#Cc1cc(Br)cc(C#C)c1C#Cc1cc(C#Cc2c(C#C)cc(C(C)(C)C)cc2C#C)c2ccc3c(C#Cc4c(C#C)cc(C(C)(C)C)cc4C#C)cc(C#Cc4c(C#C)cc(C(C)(C)C)cc4C#C)c4ccc1c2c43</smiles>

Scheme 7. Attempted synthesis of precursor 20 to DBA 11. Reagents and reaction conditions: (a) $\mathrm{CBr}_{4}, \mathrm{Ph}_{3} \mathrm{P}, \mathrm{Zn}, \mathrm{CH}_{2} \mathrm{Cl}_{2}, \mathrm{rt}, 12 \mathrm{~h}, 60 \%$; (b) $n$-BuLi, hexane/toluene, $-50^{\circ} \mathrm{C}, 1 \mathrm{~h}$; (c) LDA, THF $-78^{\circ} \mathrm{C}, 30 \mathrm{~min}$; (d) LDA, toluene/hexane, $-50^{\circ} \mathrm{C}, 1 \mathrm{~h}$.

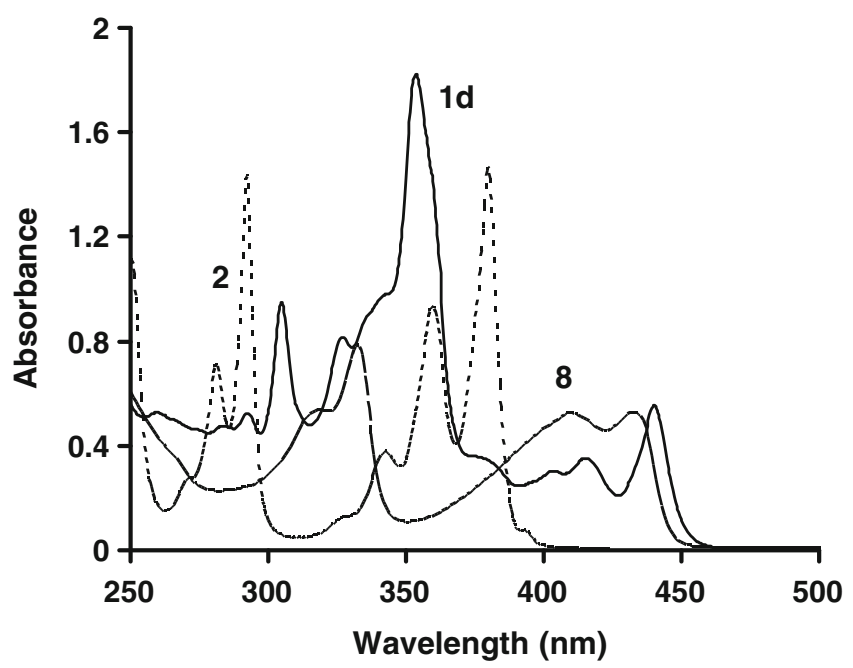

Figure 1. Absorption spectra $\left(10^{-5} \mathrm{M}\right)$ of $\mathbf{2 , 8}$ and $\mathbf{1 d}$ in $\mathrm{CH}_{2} \mathrm{Cl}_{2}$.

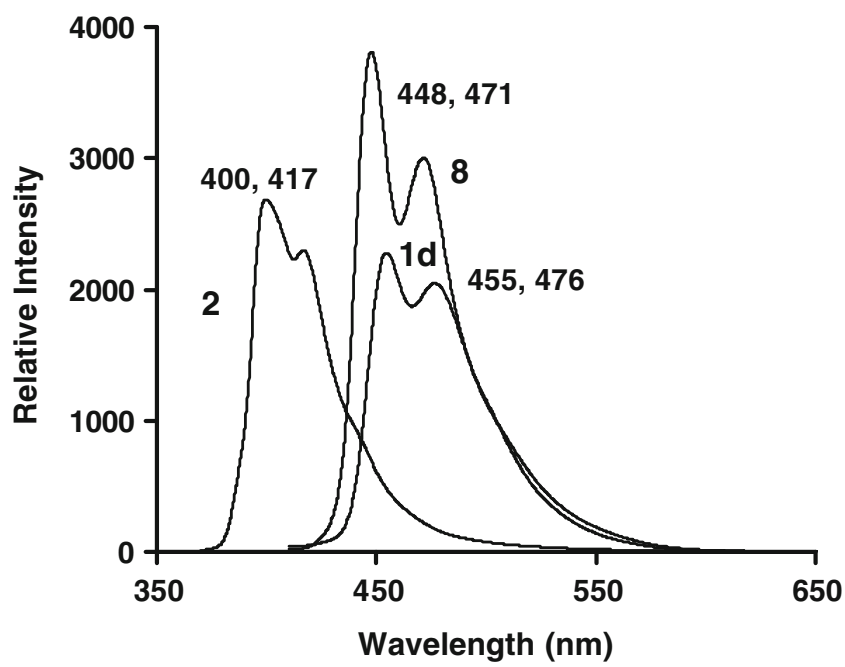

Figure 2. Fluorescence emission spectra $\left(10^{-5} \mathrm{M}\right)$ of 2 $\left(\lambda_{\text {ex }} 360 \mathrm{~nm}\right), \mathbf{8}\left(\lambda_{\mathrm{ex}} 409 \mathrm{~nm}\right)$ and $\mathbf{1 d}\left(\lambda_{\mathrm{ex}} 405 \mathrm{~nm}\right)$ in $\mathrm{CH}_{2} \mathrm{Cl}_{2}$. 


\section{Conclusion}

DBAs 1a-d with a pyrenecore have been synthesized for the first time using a sequence of Sonogashira coupling, Corey-Fuchs reaction and Eglinton coupling. A comparison of the chemical shift values of various pyrene protons of DBAs with that of their open precursors clearly showed that the peripheral protons $\mathrm{H}-4 / 5$ were deshielded and the internal protons H-9/10 were shielded in the DBAs, consistent with the closed loop of $\pi$-electrons. DBAs 1a-c, bearing long alkoxy groups did not exhibit any liquid crystalline behaviour. In comparison to $\mathbf{2}$ the absorption and emission spectra of 1a-d, $\mathbf{4 a - c}$ and $\mathbf{8}$ were red shifted due to extension of conjugation. DBA 9 was synthesized and characterized by only mass spectrometry. MALDI-MS data showed molecular ion peak corresponding to 9 along with a peak with double the $\mathrm{m} / \mathrm{z}$ value of the molecular ion, presumably due to the corresponding $\pi$-dimer. Solution phase characterization could not be done due to its insoluble nature in most common organic solvents. Synthesis of polyacetylene precursors 17 and 20 for DBAs 10 and 11, respectively, was hampered due to incomplete elimination of $\mathbf{1 6}$ and $\mathbf{1 9}$ under a variety of conditions and also presumably due to the instability of polyacetylenic derivatives $\mathbf{1 7}$ and $\mathbf{2 0}$ under reaction and ambient conditions.

\section{Acknowledgements}

We thank the Department of Science and Technology (DST) and the Council of Scientific and Industrial Research (CSIR), New Delhi for financial support. We also thank the Department of Chemistry and SAIF, Indian Institute of Technology Madras for spectral data.

\section{References}

1. (a) Staab H A and Graf F 1966 Tetrahedron Lett. 751; (b) Campbell J D, Eglinton G, Henderson W and Raphael R A 1966 J. Chem. Soc. Chem. Commun. 87; (c) Darby N, Cresp T M and Sondheimer F 1977 J. Org. Chem. 42 1960; for a recent review Spitler E L, Johnson II C A and Haley M M 2006 Chem. Rev. 1065344

2. (a) Boese R, Matzger A J and Vollhardt K P C 1997 J. Am. Chem. Soc. 119 2052; for reviews (b) Diederich F and Rubin Y 1992 Angew. Chem. Int. Ed. Engl. 31 1101; (c) Diederich F 1994 Nature 368199

3. For reviews (a) Haley M M 1998 Synlett 557; (b) Marsden J A, Palmer G J and Haley M M 2003 Eur. J. Org. Chem. 2355; (c) Bunz U H F, Rubin Y and Tobe Y 1999 Chem. Soc. Rev. 28107

4. (a) Baughman R H, Eckhardt H and Kertesz M 1987 J. Chem. Phys. 87 6687; (b) Marsden J A and Haley M M 2005 J. Org. Chem. 70 10213; (c) Sarkar A, Pak J J, Rayfield G W and Haley M M 2001 J. Mater. Chem. 11 2943

5. (a) For a review, Mitchell R H 2001 Chem. Rev. 101 1301; (b) Laskoski M, Steffen W, Smith M D and Bunz U H F 2001 Chem. Commun. 691; (c) Boydson A J, Haley M M, Williams R V and Armantrout J R 2002 J. Org. Chem. 67 8812; (d) Boydson A J and Haley M M 2001 Org. Lett. 33599

6. (a) Brandsma L, Vasilevsky S F and Verkruijsse H D 1999 Application of transition metal catalysts in organic synthesis (eds) A de Meijere and F Diederich, Berlin: Springer, 67, 179; (b) de Meijere A and Diederich F 2004 Metal-catalyzed cross-coupling reactions, Weinheim: Wiley-VCH

7. (a) For a recent review, Tobe Y and Sonoda M 2004 Modern cyclophane chemistry 11 R Gleiter and H Hopf, (Eds), Weinheim: Wiley-VCH; (b) Haley M M, Brand S C and Pak J J 1997 Angew. Chem. Int. Ed. Engl. 36 836; (c) Wan W B and Haley M M 2001 J. Org. Chem. 66 3893

8. Bandyopadhyay A, Varghese B, Hopf $\mathrm{H}$ and Sankararaman S 2007 Chem. Eur. J. 133813

9. (a) Kimball D B, Haley M M, Mitchell R H and Ward T R 2001 Org. Lett. 3 1709; (b) Kimball D B, Haley M M, Mitchell R H, Ward T R, Bandyopadhyay S, Williams R V and Armantrout J R 2002 J. Org. Chem. 678798

10. (a) Boydston A J, Bondarenko L, Dix I, Weakley T J R, Hopf $\mathrm{H}$ and Haley M M 2001 Angew. Chem. Int. Ed. 40 2986; (b) Heinrichs H, Fischer A K, Jones P G, Hopf H and Haley M M 2005 Org. Lett. 73793

11. Takeda T, Fix A G and Haley M M 2010 Org. Lett. 12 3824

12. Winnik F M 1993 Chem. Rev. 93587

13. Venkataramana G and Sankararaman S 2005 Eur. J. Org. Chem. 4162

14. Leroy-Lhez S and Fages F 2005 Eur. J. Org. Chem. 2684

15. Johnson II C A, Lu Y and Haley M M 2007 Org. Lett. 9 3725

16. (a) Chandrasekar S and Raganath G S 1990 Rep. Prog. Phys. 53 57; (b) Boden N, Bushby R J, Cammidge A N, El-Mansoury A, Martin P S and Lu Z 1999 J. Mater. Chem. 91391

17. Venkataramana G and Sankararaman S 2006 Org. Lett. 82739

18. Narayanan V, Sankararaman S and Hopf H 2005 Eur. J. Org. Chem. 2740 